\title{
FIRST RECORD OF THE GIANT PANGASIUS, PANGASIUS SANITWONGSEI (ACTINOPTERYGII: SILURIFORMES: PANGASIIDAE), FROM CENTRAL ANATOLIA, TURKEY
}

\author{
Baran YOĞURTÇUOĞLU* and F. Güler EKMEKÇİ \\ Department of Biology, Hydrobiology Section, Faculty of Science, Hacettepe University, Beytepe Campus, \\ Ankara, Turkey
}

\begin{abstract}
Yoğurtçuoğlu B., Ekmekçi F. G. 2018. First record of the giant pangasius, Pangasius sanitwongsei (Actinopterygii: Siluriformes: Pangasiidae), from central Anatolia, Turkey. Acta Ichthyol. Piscat. 48 (3): 241-244.

Abstract. Occurrence of ornamental freshwater fishes in aquatic environments has been increasing in recent years. In this study, we reported incidental wild-caught adult specimens of giant catfish, Pangasius sanitwongsei Smith, 1931, from the Sakarya River Basin in central Anatolia. This record is new for Turkish freshwaters and indicates the need for public awareness on illegal fish release and introductions as well as for preparing a sound regulation for the aquarium trade.
\end{abstract}

Keywords: Pangasius, new record, ornamental fish, aquarium trade, Turkey

\section{INTRODUCTION}

Aquarium trade has been regarded as one of the important pathways for introduction of non-indigenous species (Copp et al. 2005, Rixon et al. 2005, Nunes et al. 2015). In parallel with the global trend towards the trade network expansion, frequency of occurrence of nonnative ornamentals in natural habitats has been increasing. For example, four freshwater ornamental fish species have been reported within last few decades in Turkey: goldfish, Carassius auratus (Linnaeus, 1758) (see Innal and Erk'akan 2006), red piranha, Pygocentrus nattereri Kner, 1858 (see Tarkan 2006), vermiculated sailfin catfish, Pterygoplichthys disjunctivus (Weber, 1991), and Amazon sailfin catfish, Pterygoplichthys pardalis (Castelnau, 1855) (see Emiroğlu et al. 2016). Of the above-mentioned fishes only the goldfish and sailfin catfishes have been established.

Fishes representing another genus of non-native ornamental species- the Pangasius - often referred to as the shark catfishes, or pangas, are native to South and Southeast Asia. Even though several species of pangas are frequently imported to Turkey as popular aquarium fishes only one of them, the striped catfish, Pangasianodon hypophthalmus (Sauvage, 1878), has been confirmed in the current literature (Türkmen et al. 2001). The pangas have also become one of the new trends in the food market beside their ornamental purpose and several companies have also imported its fillets in many European countries (Rehbein 2008, Little et al. 2012). For example, the farming of striped catfish, P. hypophthalmus, began by the end of 2008 in Vietnam as a commercial freshwater species that is now a significant component of global whitefish supplies (Anonymous, unpublished ${ }^{* *}$ ). The so-called giant pangasius or dog-eating catfish, Pangasius sanitwongsei Smith, 1931, is another popular species native to the Chao Phraya and Mekong basins in Cambodia, China, Laos, Thailand, and Vietnam (Hogan et al. 2009). The species has been assessed as critically endangered since 2009 due to the several threatening factors including overfishing, river damming and increased shipping activities. The increasing popularity of pangas in both aquarium trade and food market may also lead to the records from outside of their native range. For example, two specimens of $P$. hypophthalmus were recorded in Iraq for the first time in 2011 (Khamees et al. 2013). In 2012, one specimen of P. hypophthalmus was recorded in Lake Kinneret from Israel (Snovsky and Golani 2012) and one specimen of P. sanitwongsei in Breede River from Africa (Mäkinen et al. 2013).

In this study we reported the finding of Pangasius sanitwongsei which constitutes the first record for the natural freshwaters of Turkey. Pangas' culture has not yet begun in Turkey except small-scale and unsuccessful trials in Adana and Muğla (southern Turkey). Although there is

\footnotetext{
* Correspondence: Dr. Baran Yoğurtçuoğlu, Biyoloji Bölümü, Hidrobiyoloji A.B.D., Fen Fakültesi, Hacettepe Üniversitesi, Beytepe Kampüsü, 06800, Ankara, Turkey, phone: +90 312-780-50-36, fax: +90 312-299-20-28, e-mail: (BY) yokbaran@gmail.com, (FGE)fgekmekci@gmail.com.

** Anonymous 2009. Briefing document on the current status of Vietnam's fisheries sector. Report prepared by the NAFIQAD, Post Harvesting and Marketing component under the Fisheries Sector Programme Support Phase II (FSPS II) for the Eighth FSPS II National Steering Committee Meeting, Pp. 50, Hanoi, 17 June 2009. [In Vietnamese and English].
} 
no legal frame in Turkey, regulating trials of new species for aquaculture purposes. Therefore, we hypothesized that they have been aquarium escapees most likely released by aquarium hobbyists.

\section{MATERIAL AND METHODS}

A total of four individuals of Pangasius sanitwongsei were captured from the Sariyar Reservoir in Central Anatolia $\left(40.082^{\circ} \mathrm{N}, 31.652^{\circ} \mathrm{E}\right.$, Fig. 1). The reservoir is located in a deep valley and its surface area is $84 \mathrm{~km}^{2}$ and the maximum depth is $90 \mathrm{~m}$. All specimens were caught on 31 July 2017 by local fishermen. The individuals of $P$. sanitwongsei were captured from the littoral zone up to $5 \mathrm{~m}$ depth using gillnets of $45-\mathrm{mm}$ mesh size by the fishermen who were fishing for carp. Three individuals were transferred to the laboratory in iceboxes. The fish specimens were identified up to the species level by examining morphological characteristics following Kottelat and Freyhof (2007) and diagnosed according to the characters given by Roberts and Vidthayanon (1991). Additional features taken into account were gill raker and vertebrae counts facilitated by X-ray photographing and finally dissecting. The material is deposited in the Hacettepe University Güler Ekmekçi Collection.

\section{RESULTS}

The largest specimen of Pangasius sanitwongsei was $53 \mathrm{~cm}$ in total length (TL) and $1300 \mathrm{~g}$ body weight $(W)$ (Fig. 2), and the TL and $W$ of all specimens ranged from 49 to $53 \mathrm{~cm}$ and from 1010 to $1300 \mathrm{~g}$, respectively. In the first week of August anglers shared with us the photos of another panga individuals captured by a fishing rod from two streams, Yenice and Sarısu representing the same drainage. Yet, they could not be identified since the diagnostic characters were not clearly seen from the photos due to their poor quality.

Based on the species identification key provided by Roberts and Vidthayanon (1991), the specimens from the Sariyar Reservoir are most closely matched with P. sanitwongsei by the following characters (for a general view of the specimen see Fig. 2): gill rakers, 20-21; number of vertebrae, 48-49 (Fig. 3); obvious ray extensions (Figs. 2 and 3); two-lobbed swim bladder (Fig. 3); broader head and mouth with vomero-palatine teeth on a united single arch (Fig. 4); and the mouth width $17.0 \%-17.5 \%$ of standard length (mean 17.2\%). The colour pattern is also in accordance with the diagnostic characteristics: head and the dorsal surface dark grey and getting lighter to pale white through the belly. Dark grey to black caudal fin and wide, dusty grey or black anal and dorsal fin margin.

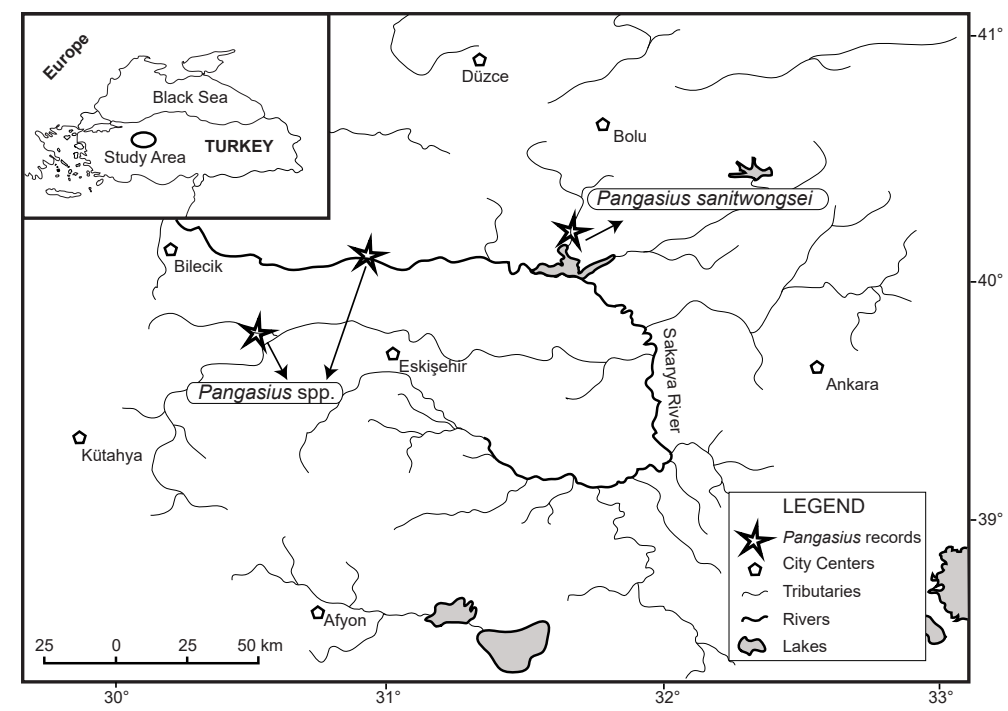

Fig. 1. Map showing the first records of Pangasius in Turkey

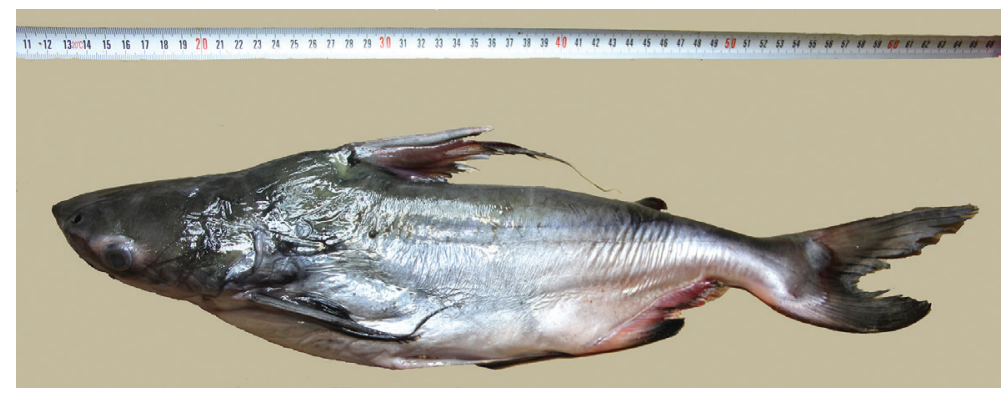

Fig. 2. Pangasius sanitwongsei from Sarıyar Dam Lake, Turkey; $53 \mathrm{~cm}$ TL 


\section{DISCUSSION}

Pangasius sanitwongsei can be distinguished from the majority of its congeners by having broad head and mouth and by its filamentous extensions located on the dorsal, anal, pectoral and pelvic fins. The individuals from the Sariyar Reservoir were easily identified based on these characteristics that are in accordance with the key points given for P. sanitwongsei by Roberts and Vidthayanon (1991), with the only exception being the vertebrae number slightly different from that key (48-49 vs. 50-52). This might be explained either by inter-population variability in vertebrae number or by rearing conditions, as it has long been known that the vertebrae number of fishes reared under artificial conditions may differ from those of their conspecifics living in natural waters (Barlow 1961). The other specimens captured from the Yenice and Sarısu streams could not be identified since we only had photos of poor quality. However, as far as they were seen, they probably belong to a Pangasius species other than P. sanitwongsei as no ray extensions could be seen. Recording more than one non-indigenous species of a genus in a river basin almost at the same time could only lead to the assumption that they come from a common or similar source. Moreover, capturing the Pangasius sp. specimens by anglers indicates their active foraging behaviour of those fish. The three invasive fish species such as Clarias gariepinus (Burchell,
1822); Oreochromis niloticus (Linnaeus, 1758); and Pterygoplichthys spp. (Emiroğlu 2011, Emiroğlu et al. 2016) have been reported to form established populations in the Sakarya River basin. The natural environment conditions in Turkey are, in general, not suitable for tropical ornamental fish except for some local, isolated warm water resources. In addition, panga species have very special and long migration pattern for reproduction (Baird et al. 2004). Captive breeding trials of $P$. hypophthalmus failed in Adana and Muğla due to the low winter temperatures. Accordingly, we presumed that the spread of Pangasius spp. is not at an alarming state at least in the southern part of Turkey (Suat Dikel pers. comm.), but potential invasiveness of pangas should also be considered.

Pangas are ranked among the largest freshwater fishes in the world reaching up to $3 \mathrm{~m}$ length and $350 \mathrm{~kg}$ weight (Roberts and Vidthayanon 1991, Stone 2007). Many people in Turkey release such large ornamental fish species into natural habitats because upon the purchase they are not informed about the potential of the fish for reaching eventually large size. We believe that the public awareness on illegal fish release and introductions must be raised. Regulating fishery laws and legislation for aquarium trade through performing risk assessments is important. Ornamental fishes with aquaculture potential should be assessed as well in terms of their possible risks before permitted to be farmed.

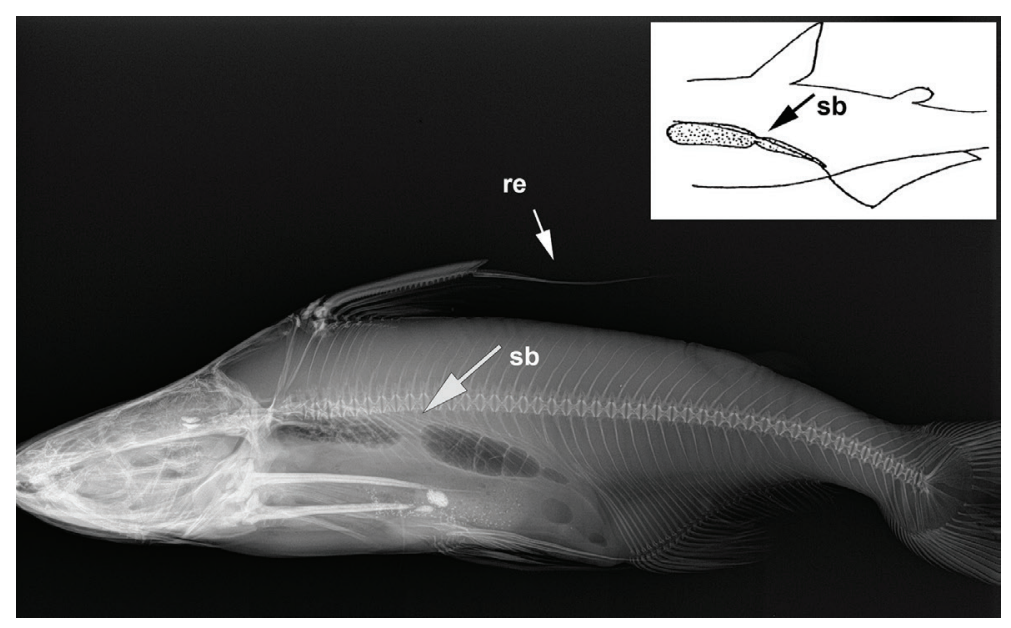

Fig. 3. Radiographic image of Pangasius sanitwongsei from Sarıar Dam Lake, Turkey; $53 \mathrm{~cm}$ TL; sb = swim bladder; re $=$ ray extension
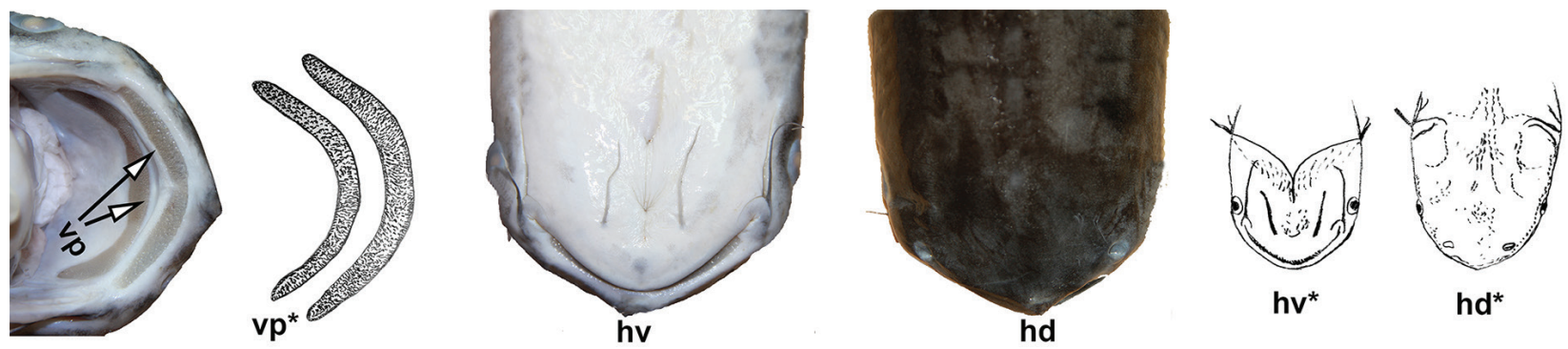

Fig. 4. Some diagnostic characteristics from the head region of Pangasius sanitwongsei from Saryyar Dam Lake; vp = vomero-palatine teeth, $\mathrm{hv}=$ head from the ventral side, $\mathrm{hd}=$ head from the dorsal side; Images were re-drawn and/or modified from Roberts and Vidthayanon (1991) 


\section{ACKNOWLEDGEMENTS}

We would like to thank Mr. Erşan İlhan for all his collaboration in obtaining and transportation of fish specimens. We are pleased to thank Dr. Özgür Emiroğlu (Osmangazi University), who shared with us the information about the pangas caught in Yenice and Sarısu. We would also like to thank Prof. Dr. Feza Korkusuz (Hacettepe University Faculty of Medicine) for his help in radiographing and to Mr. M Altuğ Atalay (T.R. Ministry of Food and Agriculture) and Dr. Suat Dikel for sharing valuable information and for comments.

\section{REFERENCES}

Barlow G.W. 1961. Causes and significance of morphological variation in fishes. Systematic Biology 10 (3): 105-117. DOI: 10.2307/2411595

Copp G.H., Bianco P.G., Bogutskaya N.G., Erős T., Falka I., Ferreira M.T., Fox M.G., Freyhof J., Gozlan R.E., Grabowska J., Kováč V., MorenoAmich R., Naseka A.M., Peňáz M., Povz M., Przybylski M., Robillard M., Russell I.C., Stakėnas S., Šumer S., Vila-Gispert A., Wiesner C. 2005. To be, or not to be, a non-native freshwater fish? Journal of Applied Ichthyology 21 (4): 242-262. DOI: 10.1111/j.1439-0426.2005.00690.x

Emiroğlu Ö. 2011. Alien fish species in upper Sakarya River and their distribution. African Journal of Biotechnology 10 (73): 16674-16681. DOI: 10.5897/ AJB10.2502

Emiroğlu Ö., Ekmekçı F.G., Aksu S., Başkurt S., Atalay M.A., Tarkan A.S. 2016. Introduction and establishment of tropical ornamental fish, Pterygoplichthys spp. (Actinopterygii: Siluriformes: Loricariidae) in hot springs: Aquarium trade as a potential risk for biodiversity in Turkey. Acta Ichthyologica et Piscatoria 46 (4): 351-356. DOI: 10.3750/AIP2016.46.4.07

Hogan Z., Na-Nakorn U., Kong H. 2009. Threatened fishes of the world: Pangasius sanitwongsei Smith 1931 (Siluriformes: Pangasiidae). Environmental Biology of Fishes 84 (3): 305-306. DOI: 10.1007/ s10641-008-9419-6

Innal D., Erk'akan F. 2006. Effects of exotic and translocated fish species in the inland waters of Turkey. Reviews in Fish Biology and Fisheries 16 (1): 39-50. DOI: $10.1007 / \mathrm{s} 11160-006-9005-\mathrm{y}$

Khamees N.R., Ali A.H., Abed J.M., Adday T.K. 2013. First record of striped catfish Pangasianodon hypophthalmus (Sauvage, 1878) (Pisces: Pangasiidae) from inland waters of Iraq. Basrah Journal of Agricultural Sciences 26 (Special Issue 1): 184-197.

Kottelat M., Freyhof J. 2007. Handbook of European freshwater fishes. Kottelat, Cornol, Switzerland and Freyhof, Berlin, Germany.

Little D.C., Bush S.R., Belton B., Phuong N.T., Young J.A., Murray F.J. 2012. Whitefish wars: Pangasius, politics and consumer confusion in Europe. Marine Policy 36 (3): 738-745. DOI: 10.1016/j. marpol.2011.10.006

Mäkinen T., Weyl O.L.F., van der Walt K.-A., Swartz E.R. 2013. First record of an introduction of the giant pangasius, Pangasius sanitwongsei Smith 1931, into an African river. African Zoology 48 (2): 388-391. DOI: 10.3377/004.048.0209

Nunes A.L., Tricarico E., Panov V.E., Cardoso A.C., Katsanevakis S. 2015. Pathways and gateways of freshwater invasions in Europe. Aquatic Invasions $\mathbf{1 0}$ (4): 359-370. DOI: 10.3391/ai.2015.10.4.01

Rehbein H. 2008. New fish on the German market: Consumer protection against fraud by identification of species. Journal Fur Verbraucherschutz Und Lebensmittelsicherheit 3 (1): 49-53. DOI: 10.1007/ s00003-007-0301-9

Rixon C.A.M., Duggan I.C., Bergeron N.M.N., Ricciardi A., MacIsaac H.J. 2005. Invasion risks posed by the aquarium trade and live fish markets on the Laurentian Great Lakes. Biodiversity and Conservation 14 (6): 1365-1381. DOI: 10.1007/s10531-004-9663-9

Roberts T.R., Vidthayanon C. 1991. Systematic revision of the Asian catfish family Pangasiidae, with biological observations and descriptions of three new species. Proceedings of the Academy of Natural Sciences of Philadelphia 143: 97-144.

Snovsky G., Golani D. 2012. The occurrence of an aquarium escapee, Pangasius hypophthalmus (Sauvage, 1878), (Osteichthys, Siluriformes, Pangasiidae) in Lake Kinneret (Sea of Galilee), Israel. BioInvasions Records 1 (2): 101-103. DOI: 10.3391/ bir.2012.1.2.03

Stone R. 2007. The last of the Leviathans. Science 316(5832): 1684-1688. DOI: 10.1126/science.316.5832.1684

Tarkan A.S. 2006. Sapanca Gölü'nden Bir Pirana Hikayesi. [A piranha story from Sapanca Lake.] Av Doğa 41: 75-77.

Türkmen G., Alpbaz A. 2001. Türkiye'ye ithal edilen akvaryum balıkları ve sonuçları üzerine araştırmalar. [Results of a study on aquarium fish imported to Turkey.] Ege University Journal of Fisheries and Aquatic Sciences 18 (3): 483-493 [In Turkish.]

Received: 14 February 2018 Accepted: 12 April 2018 Published electronically: 30 September 2018 